\title{
Characteristic and affecting factors of wetland herbs' distribution in the radiant belt toward land of lake-terrestrial ecotone in Tibet, China
}

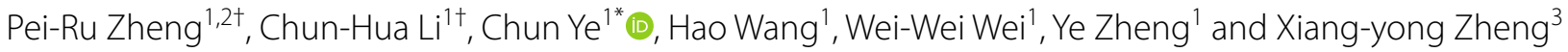

\begin{abstract}
Background: Lake is a critical part of Tibet's hydrological cycle, the lake-terrestrial ecotone is the most sensitive area in the water and terrestrial ecosystem. For the ecological protection and maintenance of the lakeside zone, defining the upper boundary of the lake-terrestrial ecotone is a key issue that needs to be solved urgently. However, the ecological characteristics of lake-terrestrial ecotone made it difficult to delimit. Wetland herbs are characteristic plants of the lake-terrestrial ecotone, and their distribution width can be used to reflect the upper boundary of the lake-terrestrial ecotone. We took Baksum Lake, Yamdroktso, Namtso, Siling Co as examples, based on the spatial structure of the lake-terrestrial ecotone, used the moving split-window technology (MSWT) delimited the width of wetland herbs.

Results: The results of the MSWT showed the distribution width of wetland herbs in each lake-terrestrial ecotone with the natural-wetland type sampling line of Baksum Lake, Yamdroktso, Namtso, Siling Co was $51 \mathrm{~m}, 56 \mathrm{~m}$, $33 \sim 53 \mathrm{~m}, 19 \sim 31 \mathrm{~m}$. The detrended correspondence analysis (DCA) showed quantity of wetland herbs species, BK1 $>\mathrm{YT} 1=\mathrm{NT} 1>\mathrm{NT} 2>\mathrm{SC} 1=\mathrm{SC}$. The principal component analysis (PCA) and the (redundancy analysis) RDA showed soil moisture content (SMO), $\mathrm{pH}$, soil moisture content (SSC), and soil nutrient content had obvious correlation with distribution width.
\end{abstract}

Conclusion: The MSWT was a feasible method to determine the width of lake_terrestrial ecotone. SMO, pH, SSC, and soil nutrient content were all important environmental factors affecting the wetland herbs distribution width of the four lakes; and the SMO was the most important factor. Besides, compared with the lakes in the Middle-Lower Yangtze Plain, the high-density population distribution, high-intensive human activity invaded the plants' growth area, resulting in a smaller distribution width. The distribution edge of wetland herbs is equivalent to the upper boundary of lake-terrestrial ecotone. It determines the management boundary of the lake-terrestrial ecotone, provides a theoretical basis for the construction of environmental protection projects, and is of great significance to the lake ecological restoration and management in watershed control planning.

Keywords: Lake-terrestrial ecotone, Moving split-window technology, Wetland herbs, Tibetan lakes

*Correspondence: yechbj@163.com

${ }^{\dagger}$ Pei-Ru Zheng and Chun-Hua Li contributed equally to this work ${ }^{1}$ National Engineering Laboratory for Lake Pollution Control and Ecological Restoration, State Environmental Protection Key Laboratory for Lake Pollution Control, Chinese Research Academy of Environmental Sciences, Beijing 100012, China

Full list of author information is available at the end of the article

\section{Background}

Lake-terrestrial ecotone is an important part of the lake ecosystem. It has the functions of intercepting pollutants carried by surface overflow, runoff, and underflow; providing habitat for wild animals, and improving the ecological diversity of lakes [1]. In human history, water has

\section{Springer Open}

(c) The Author(s) 2022. Open Access This article is licensed under a Creative Commons Attribution 4.0 International License, which permits use, sharing, adaptation, distribution and reproduction in any medium or format, as long as you give appropriate credit to the original author(s) and the source, provide a link to the Creative Commons licence, and indicate if changes were made. The images or other third party material in this article are included in the article's Creative Commons licence, unless indicated otherwise in a credit line to the material. If material is not included in the article's Creative Commons licence and your intended use is not permitted by statutory regulation or exceeds the permitted use, you will need to obtain permission directly from the copyright holder. To view a copy of this licence, visit http://creativecommons.org/licenses/by/4.0/. 
been the major attractor for human geographical location and distribution [2]. Lake-terrestrial ecotone is the most susceptible part of lake ecosystem [3]. From the perspective of economic development, flood protection, tourism, and other highly intensive anthropogenic activities, as well as unsustainable and uncontrolled development in lake-terrestrial ecotone trigger severe disturbances in the lake-terrestrial ecotone ecosystem and accelerate ecosystem degradation [4]. As the necessity for ecological environment protection has intensified, considerable restoration activities have been implemented on laketerrestrial ecotone [5-10]. Lake-terrestrial ecotone with natural-wetland type (Fig. 1) is usually used as a good example for eco-restoration. It includes three parts, namely, radiant belt toward the land, shoreline zone and radiant belt toward the lake. Currently, width delimitation is the primary step in lake-terrestrial ecotone protection and restoration. Natural-wetland type laketerrestrial ecotone naturally feature vegetation changes, primarily manifested in the transition from wetland plants to mesophytes and xerophytes. As they are very sensitive to soil moisture changes, the distribution width of wetland plants can be used to express the boundary of the lake-terrestrial ecotone [1]. According to the plant life form, wetland plants category as trees, shrubs, herbs. Compared with trees and shrubs that can absorb water and nutrients from deeper soil, herbs were more sensitive to soil moisture fluctuation [11]. Therefore, the herbs can better reflect the upper boundary of lake-terrestrial ecotone. The authors propose that the width of the laketerrestrial ecotone with the natural-wetland type can consider as extending from the lake's multi-year average high-water line to the edge of the disappearance of wetland herbs. Thus, there is an exigent need to accurately delimit the distribution width of wetland herbs in laketerrestrial ecotone with natural-wetlands.

Moving split-window technology (MSWT) is widely used to delimit the boundaries of the chemical and physical characteristics of soil and the boundaries of vegetation or animal communities [12-15]. MSWT can eliminate the errors due to sampling deviations of individual samplings and can express the position and width of the ecotone more objectively than other methods [16]. MSWT is widely used as well as the most effective method for analyzing the boundaries of an ecotone [17]. MSWT was proved as being able to accurately delimit the width and boundaries of vegetation or animal communities and soil nutrient content [18-26]. Therefore, we selected MSWT to delimit the boundary of the wetland herbs-mesophyte/xerophyte transition zone and further use this boundary as an upper limit of the lake-terrestrial ecotone with natural-wetlands.

The distribution of herbs is affected by the combined effects of different environmental factors. Lake-terrestrial ecotone is a relatively small spatial scale; therefore, except climatic factors, factors such as micro-topography, soil physical and chemical conditions, and hydrology needed to be considered [27]. Topographic and

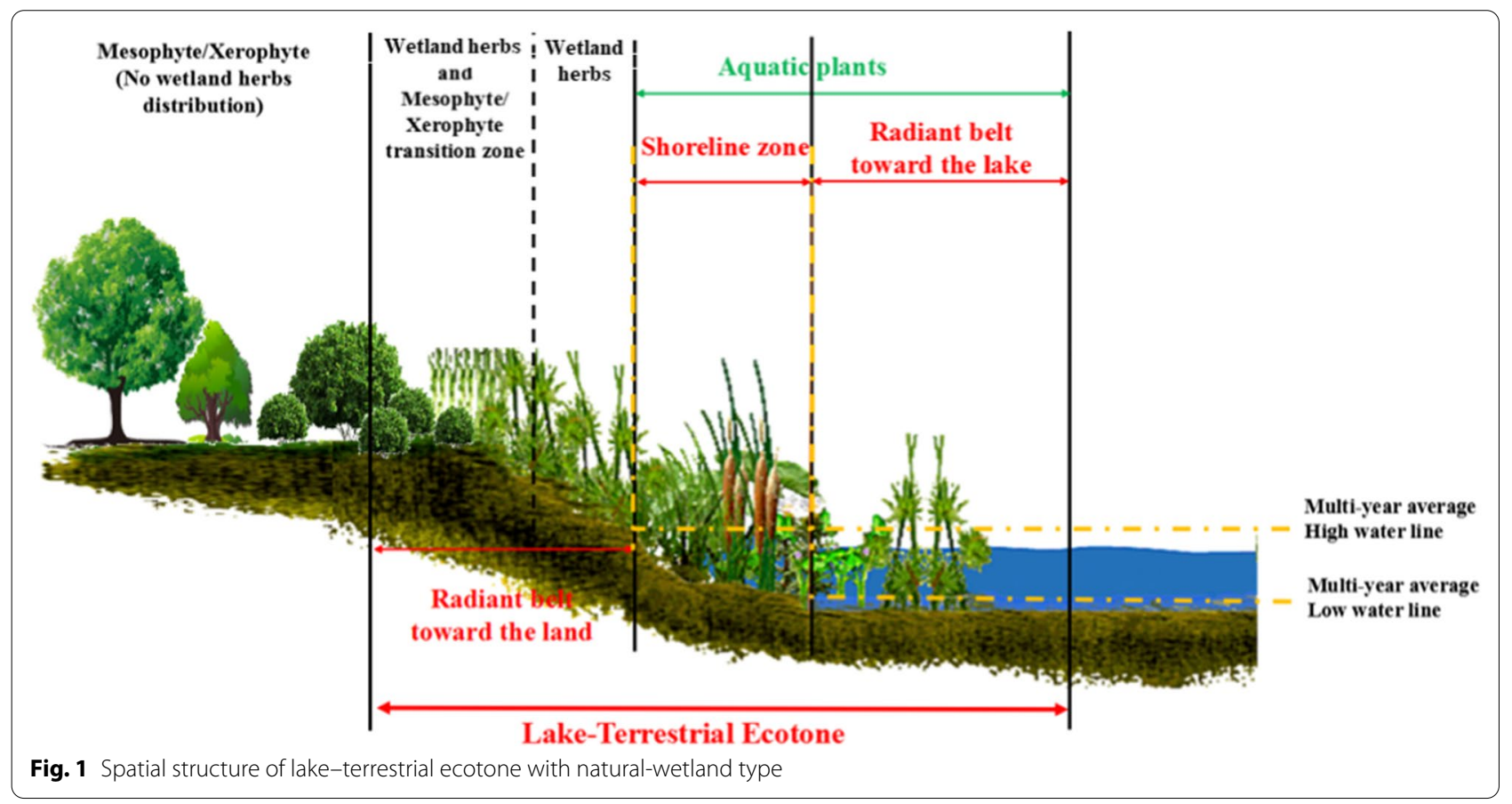


geomorphological factors (altitude and slope) affect spatial redistribution of solar radiation and surface water distribution [28], thus influencing the growth and distribution of wetland herbs. In contrast with other environmental factors, soil physical and chemical conditions (soil type, soil nutrient, soil moisture, soil $\mathrm{pH}$, soil salinity, etc.) directly affect the distribution of wetland herbs [29-31]. Examining wetland herbs biodiversity, distribution characteristics, and influencing factors will help understand the relationship between the wetland herbs distribution width and the lake-terrestrial ecotone habitat factors. Moreover, prediction of the dynamic changes in the spatial range of the lake-terrestrial ecotone will reveal the formation mechanism of the distribution pattern of wetland herbs as well as the ecological process of community succession and its internal mechanisms. The latter plays a significant role in the lake protection and restoration processes $[1,3]$.

The Tibetan Plateau features the largest number of lakes in China ( $>1500$ lakes); most of these are salt lakes [32], and more than $97 \%$ as inland lakes [33]. Lakes play a key role in the hydrological cycle in Tibet and greatly affect the regional climate, water resources, and terrestrial/aquatic ecosystems [34]. The lakes in Tibet can be classified based on the distribution characteristics of river systems and lakes: (1) outflow lake areas in southeast Tibet, (2) outflow-inland lake areas in southern Tibet, and (3) inland lake areas in northern Tibet. The lakes in Tibet are located at high altitudes and in extreme climatic conditions and thus, are less affected by anthropogenic activities. Natural wetlands are the primary type of lake-terrestrial ecotone. However, in recent years, with the mining of minerals [35], livestock breeding in the region has increased [36]; further, the construction of roads and railways [37] have severely disturbed the laketerrestrial ecotone ecological environment in Tibet. In addition to anthropogenic disturbances, changes in lake water level also affect the ecological environment of the lake-terrestrial ecotone. For instance, the expansion of the lake area in Siling Co Lake has led to the degradation of the alpine grasslands and meadows in the lake area [38, 39]. The lake ecosystems in Tibet are very vulnerable to human and natural disturbances, with minor changes leading to irreversible degradation of the regional ecosystems [40, 41]. However, cold-tolerant and salt-tolerant wetland herbs can survive under extreme climatic conditions. Thus, even under harsh environmental conditions of Tibet, at the highest altitude worldwide, wet plants are widely distributed across the entire region.

The aim of this study is to delimit the distribution width of wetland herbs of lake-terrestrial ecotone and their influencing factors that have great significance for the protection of the Tibetan lakes. We examine four lakes encompassing three aforementioned classes of Tibetan lakes including: Baksum Lake (outflow lake area in southeastern Tibet), Yamdroktso (outflow-inland lake area from southern Tibet), Namtso and Siling Co lakes (inland lake area of northern Tibet). Further, we (a) used MSWT to delimit the distribution width of wetland herbs of the lake-terrestrial ecotone; (b) surveyed the average annual temperature (AAT), average annual rainfall (AAR), altitude, slope, and soil characteristics to explain the environmental factors that influence the wetland herbs distribution; and (c) analyzed the relationship among environmental factors, wetland herbs species composition, and community diversity index to determine the main influencing factors of the wetland herbs distribution width.

\section{Materials and methods Study area}

We chose the following typic lakes in Tibet: Baksum Lake, an outflow lake area in southeastern Tibet, Yamdroktso, an outflow-inland lake area in southern Tibet, and Namtso and Siling Co, two inland lakes in northern Tibet (Fig. 2). The natural environmental information on the four lakes is summarized in Table 1. Basing on field survey, six typic lake-terrestrial ecotones with naturalwetland type were selected as sampling areas, their location is shown in Fig. 2.

\section{Width delimitation method}

The moving split-window technology (MSWT) was applied to delimit the distribution width of wetland herbs. The MSWT divides a segmentation window into two half-windows $(A$ and $B$ ) by calculating the difference coefficient between $A$ and $B$. Then, one point is moved down in order, and the difference coefficient is calculated until every quadrat on the sampling strip participates in the calculation (Fig. 3a) [51, 52]; Here, the distance coefficient is used as the ordinate and the sampling number as the abscissa. The peak value generated by the drawing was expressed as the location of the wetland herbs and mesophytic/xerophyte transition zone in the lake-terrestrial ecotone, and the peak width was expressed as the width of this transition zone. The endpoint of the peak width was the boundary between the transition zone and the adjacent ecosystem [20]. The distance from the endpoint of the peak width to the starting point of the sampling line was the distribution width of wetland herbs in the lake-terrestrial ecotone.

When the MSWT was applied to delimit the distribution width of wetland herbs, the distance coefficient and calculation index should be selected at the first. The distance coefficient is mostly determined by Squared Euclidean Distance (SED), Percent Dissimilarity (PD) which 


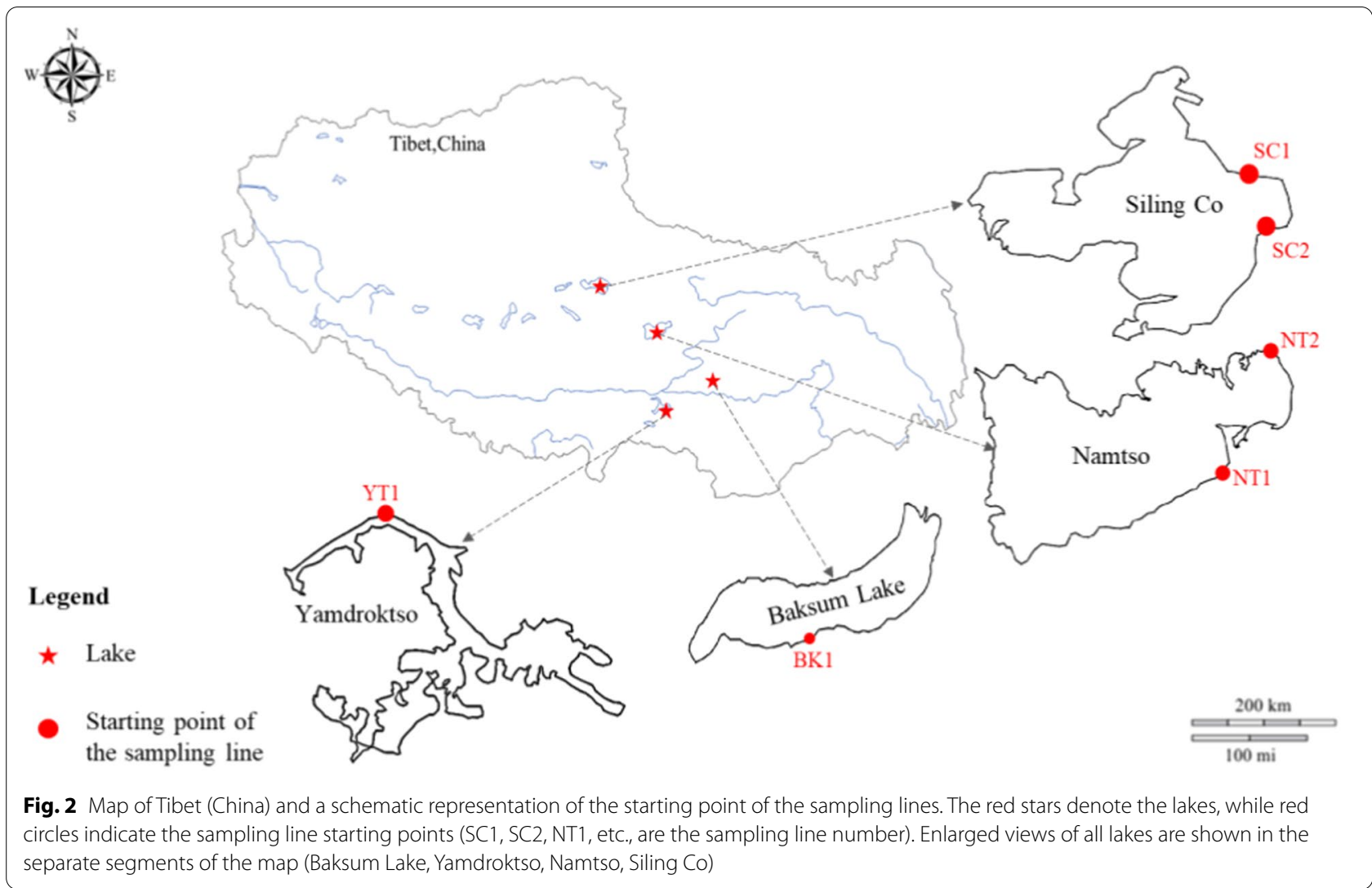

Table 1 The natural environmental information on the Baksum Lake, Yamdroktso, Namtso and Siling Co

\begin{tabular}{|c|c|c|c|c|c|c|c|c|c|}
\hline Lake & Altitude/m & Latitude & Longitude & Climate & $\mathrm{AAR} / \mathrm{mm}$ & $\mathrm{AAT} /{ }^{\circ} \mathrm{C}$ & $\begin{array}{l}\text { Lake } \\
\text { Area/ } \\
\text { km }^{2}\end{array}$ & $\begin{array}{l}\text { Lake } \\
\text { water } \\
\text { pH }\end{array}$ & References \\
\hline $\begin{array}{l}\text { Baksum } \\
\text { Lake }\end{array}$ & 3480 & $31^{\circ} 00^{\prime} 01^{\prime \prime} \mathrm{N}-31^{\circ} 22^{\prime} 53^{\prime \prime} \mathrm{N}$ & $93^{\circ} 53^{\prime} 37^{\prime \prime} \mathrm{E}-94^{\circ} 1^{\prime} 48^{\prime \prime} \mathrm{E}$ & $\begin{array}{l}\text { Plateau } \\
\text { temperate } \\
\text { Monsoon } \\
\text { semi- } \\
\text { humid / } \\
\text { semi-arid } \\
\text { climate }\end{array}$ & $600-700$ & 6.0 & 26 & 7.2 & [42] \\
\hline $\begin{array}{l}\text { Yamdrok- } \\
\text { tso }\end{array}$ & 4441 & $28^{\circ} 27^{\prime} 00^{\prime \prime} \mathrm{N}-29^{\circ} 12^{\prime} 00^{\prime \prime} \mathrm{N}$ & $90^{\circ} 08^{\prime} 00^{\prime \prime} \mathrm{E}-91^{\circ} 45^{\prime} 00^{\prime \prime} \mathrm{E}$ & $\begin{array}{l}\text { Plateau } \\
\text { sub-frigid } \\
\text { Monsoon } \\
\text { semi-arid } \\
\text { climate }\end{array}$ & 373.0 & 2.4 & 638 & $9.2-9.3$ & {$[43,44]$} \\
\hline Namtso & 4718 & $30^{\circ} 30^{\prime} 00^{\prime \prime} \mathrm{N}-30^{\circ} 55^{\prime} 00^{\prime \prime} \mathrm{N}$ & $90^{\circ} 16^{\prime} 00^{\prime \prime} \mathrm{E}-91^{\circ} 03^{\prime} 00^{\prime \prime} \mathrm{E}$ & $\begin{array}{l}\text { Plateau } \\
\text { sub-frigid } \\
\text { Monsoon } \\
\text { semi-arid } \\
\text { climate }\end{array}$ & $\begin{array}{l}\text { North } \\
\text { shore: } \\
301.2 \\
\text { South } \\
\text { shore: } \\
486.9\end{array}$ & $\begin{array}{l}\text { North } \\
\text { shore: } 0.4 \\
\text { South } \\
\text { shore: } 1.3\end{array}$ & 2020 & $7.8-9.5$ & {$[45-47]$} \\
\hline Siling Co & 4530 & $31^{\circ} 34^{\prime} 00^{\prime \prime} \mathrm{N}-31^{\circ} 51^{\prime} 00^{\prime \prime} \mathrm{N}$ & $88^{\circ} 33^{\prime} 00^{\prime \prime} \mathrm{E}-89^{\circ} 21^{\prime} 00^{\prime \prime} \mathrm{E}$ & $\begin{array}{l}\text { Plateau } \\
\text { sub-frigid } \\
\text { Monsoon } \\
\text { semi-arid/ } \\
\text { plateau } \\
\text { cold arid } \\
\text { climate }\end{array}$ & $290-321$ & 0.2 & 2391 & $9.4-9.7$ & {$[48-50]$} \\
\hline
\end{tabular}




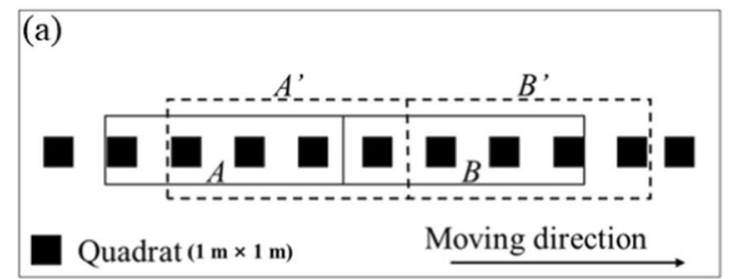

(5) Bray-Curtis distance coefficient [53]. Since the most iconic feature of lake-terrestrial ecotone is the vegetation changes, in our previous research, we compared the species richness and the important value (IV) of wetland herbs, which can reflect the essential characteristics of plant communities as an index used to calculate the distance coefficient, PD and SED as distance coefficient, we found the most suitable combination of calculation index and distance coefficient is SED(IV) [54], therefore, in this study we used SED as the distance coefficient and IV of wetland herbs as the calculation index. Equations 1 and 2 explain these parameters, respectively. SED calculation formula:

$$
S E D_{n}=\sum_{i=1}^{m}\left(\bar{X}_{i A}-\bar{X}_{i B}\right)^{2} .
$$

$S E D_{n}$ is the squared euclidean distance with a window $n$, while $A$ and $B$ are two adjacent windows for a window $n$. These are the average values of the $A$ and $B$ half-windows when the parameter is $i(i$ is the importance value of hygroscopic herbaceous plants in the sampling quadrat), while $m$ is the number of parameters.

IV calculation formula:

$$
\mathrm{IV}_{a}=\left(\frac{D_{a}}{\sum D}+\frac{C_{a}}{\sum C}+\frac{F_{a}}{\sum F}\right) \times 100 \times \frac{1}{3}
$$

$\mathrm{IV}_{a}$ is the importance value of species a in the sampling quadrat; $D_{\mathrm{a}}$ is the density of species a in the sampling quadrat; $\sum D$ is the sum of the density of all plant species in the sampling quadrat; $C_{a}$ is the coverage of species $a$ in the sampling quadrat; $\sum C$ is the sum of the coverage of all plant species in the sampling quadrat; $F_{a}$ is the frequency of species $a$ in the sampling quadrat; $\sum F$ is the sum of the frequency of all plant species in the sampling quadrat.

\section{Sampling and environmental parameters measurement}

The sampling line with the high-water level was set as a starting point. On each sampling line, a sampling quadrat $(1 \times 1 \mathrm{~m})$ was set up with equal intervals, whereas all quadrats that contain wetland herbs were numbered (Fig. 3b). The name, species, density, coverage, and frequency of each species in the quadrat were recorded and used to estimate important values such as plant community richness and plant community diversity index. The altitude and slope of the lake-terrestrial ecotone were read by Global Positioning System (GPS) program in a smart mobile phone. The surface soil $(0-15 \mathrm{~cm})$ in the quadrat were collected, and the soil sample was transported to the laboratory for cold storage. soil moisture (SMO) was determined by the drying method [55]; the SSC was measured by the conductivity method [56]; soil $\mathrm{pH}$ was measured using the potentiometric method (the water-soil ratio was 2.5:1) [57]; soil organic matter content $(\mathrm{SOM})$ was measured by low-temperature external heating potassium dichromate oxidation-colorimetric method [58]; soil total carbon content (STC) and soil total nitrogen content (STN) were measured using elemental analyzer (EA3000 elemental analyzer, Italy); soil total phosphorus content (STP) was quantified by the Standards, Measurements and Testing Programme (SMT) method [59].

\section{Data analysis}

The MSWT was used to delimit the distribution width of wetland herbs in each lake-terrestrial ecotone sampling line, the principal component analysis (PCA) was applied to analyze the main environmental factors that affect the distribution width of wetland herbs, the detrended correspondence analysis (DCA) was used to analyze the distribution characters of wetland herbs in each sampling line, 
while the redundancy analysis (RDA) was used to examine the response relationship between the environmental factors and the plant diversity index. The PCA, DCA, and RDA were calculated using the CANOCO 5.0 software. Origin 8.0 software was used for data analysis and figure plotting.

\section{Results}

\section{Distribution of wetland herbs in various sampling lines}

In total, 101 quadrats $(1 \times 1 \mathrm{~m})$ were sampled on laketerrestrial ecotones of four lakes in Tibet. A total of 33 wetland herbs from 21 branches were investigated. The dominant wetland herbs were Rosaceae, Ranunculaceae, and Polygonaceae. There were four Rosaceae species, three Ranunculaceae species and three Polygonaceae species were found, accounting for 12.12, 9.09 and $9.09 \%$ of the overall species, respectively. The vegetation coverage of BK1, YT1, and NT1 was relatively high, ranging from 65 to $95 \%$. The DCA analysis (Fig. 4) showed that BK1, YT1, NT1, NT2, SC1, and SC2 had 23, 9, 9, 7, 3, and 3 kinds of wetland herbs, respectively. NT2 and SC1-2 had fewer wetland herb species, lower species richness and lower community diversity indices compared to those of BK1 and YT1 (Fig. 4). It probably due to the sites of NT2 and SC1-2 had worse climate and soil condition. The field survey of SC1-2 revealed that the wetland herbs of these two sampling lines primarily belong to Suaeda glauca and Achnatherum splendens, with a vegetation coverage of $\sim 1-18 \%$ (Fig. 5).

\section{Characteristics of environmental factors and plant diversity index at each lake-terrestrial ecotone sampling line}

Figure 6 shows the AAT, AAR, altitude, slope, soil $\mathrm{pH}$, SMO, SSC, SOM, STC, STN, and STP values of each

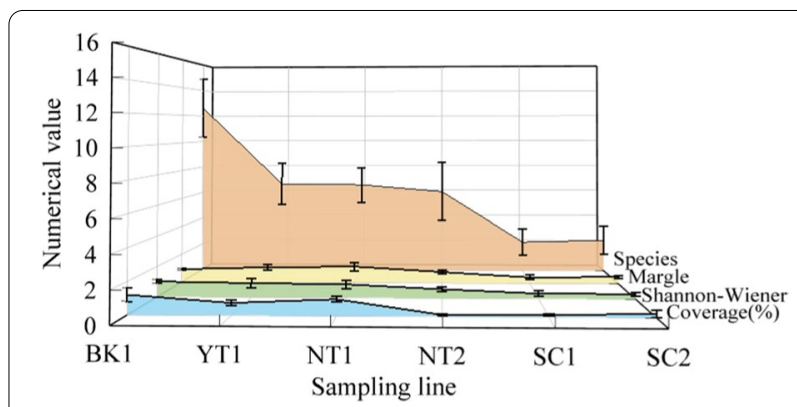

Fig. 5 Numerical value of Species (orange), the Shannon-Wiener index (green), the Margalef index (yellow), coverage (blue) index of each sampling line
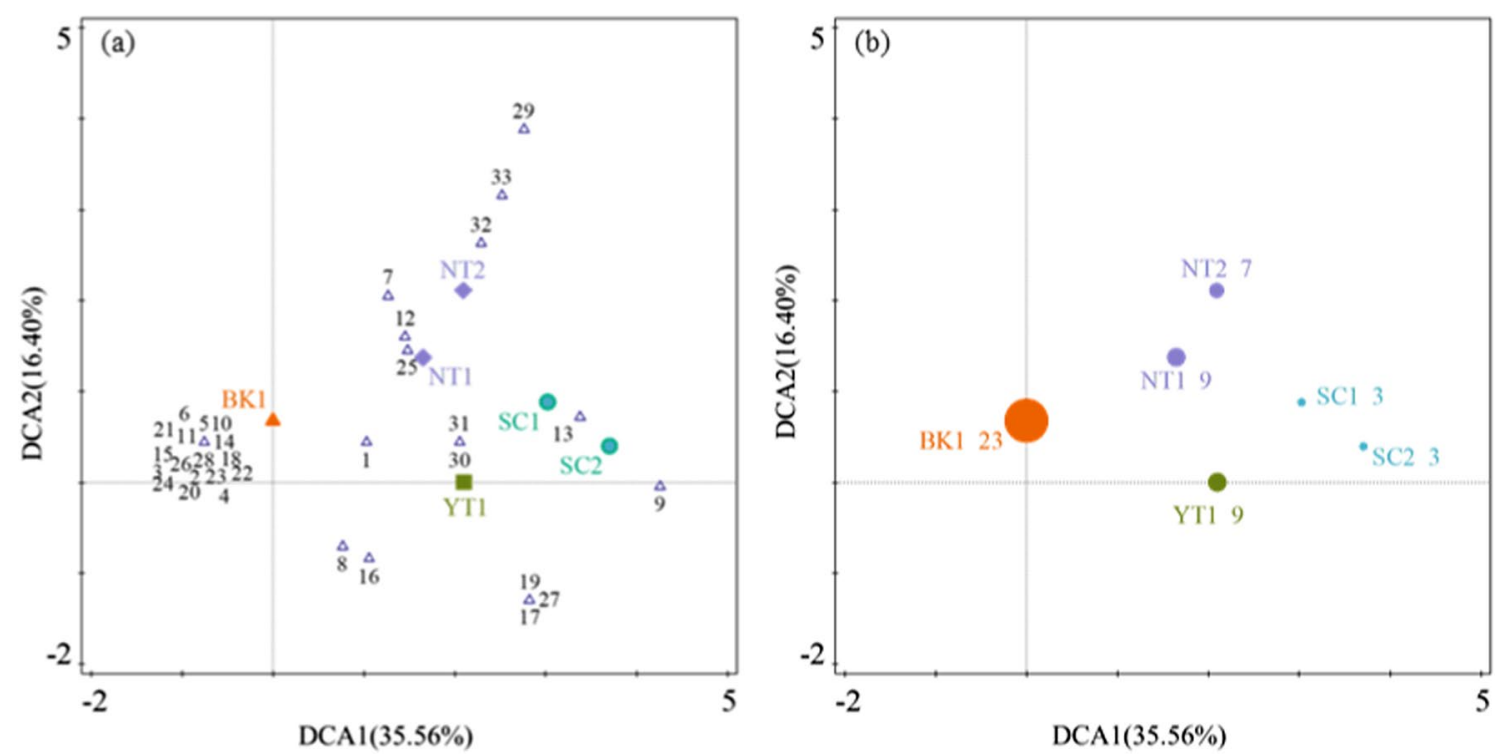

Fig. 4 Use the DCA to show the species of wetland herbs distributed in each sampling line $\mathbf{a}$ species of wetland herbs, $\mathbf{b}$ numbers of species distributed in BK1 (orange), YT1 (green), NT1 2 (purple), SC1 2 (blue). The circle size of dot in b represents the quantity of species of wetland herbs. The numbers in the picture represent plants:1. Cardamine macrophylla 2. Acorus calamus L. 3. Potentilla supina L. 4. Ranunculus muricatus 5. Cicuta virosa 6. Lamiophlomis rotata 7. Selaginella nipponica 8. Salvia przewalskii 9. Achnatherum splendens 10. Rorippa indica 11. Ranunculus tanguticus 12. Halerpestes sarmentosa 13. Suaeda glauca 14. Juncus prismatocarpus 15. Agrostis clavata 16. Potentilla anserina L. 17. Polygonum nepalense 18. Geranium nepalense 19. Aster tataricus 20. Plantago depressa 21. Galinsoga parviflora 22. Rumex acetosa L. 23. Duchesnea indica 24. Geranium sibiricum 25. Pedicularis longiflora 26. Adoxa moschatellina L.27. Polygonum sibiricum 28. Commelina diffusa 29. Astragalus scaberrimus 30. Gentiana pseudoaquatica 31. Potentilla reptans var. sericophylla 32. Ophioglossum vulgatum 33. Asplenium trichomanes 

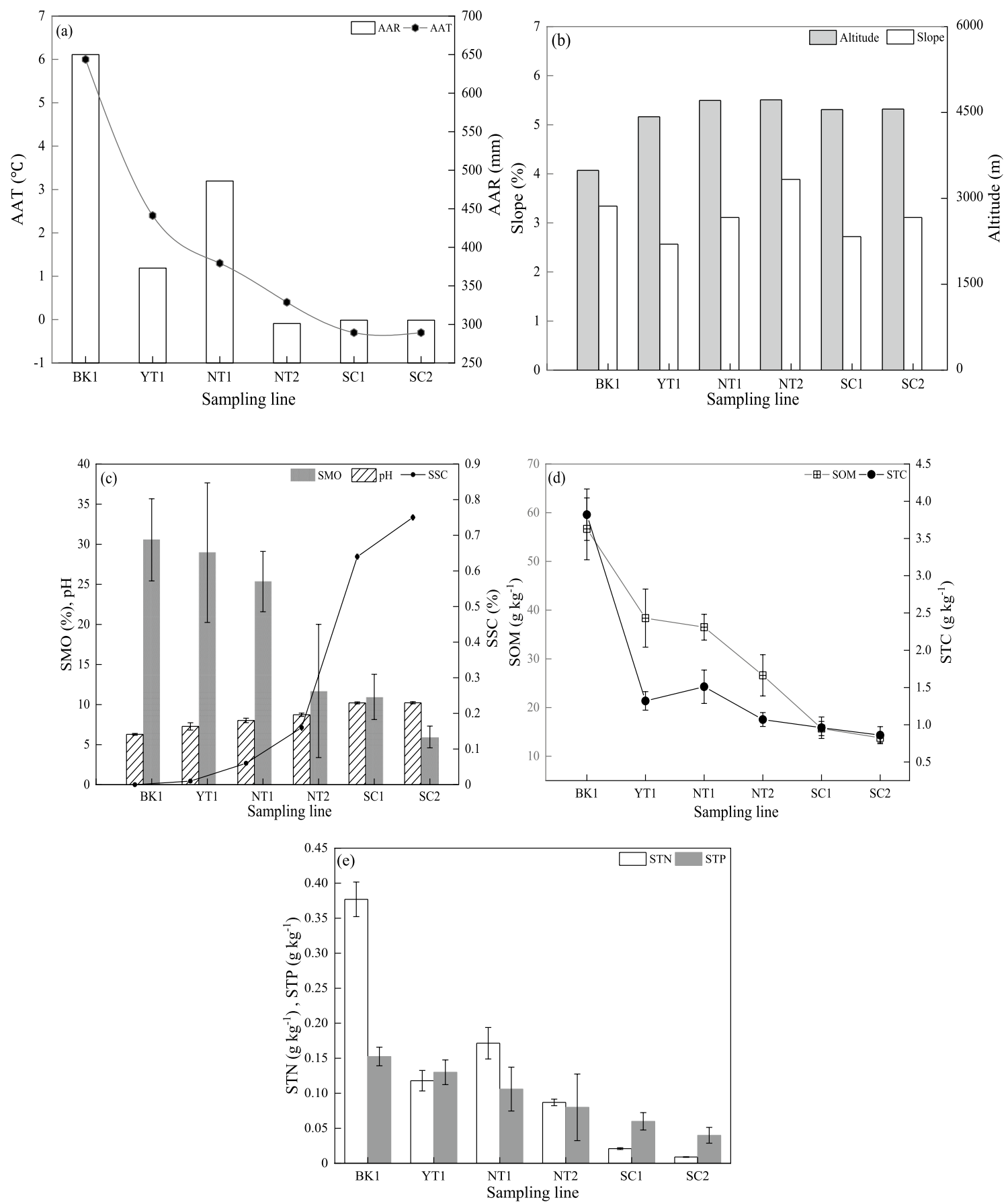

Fig. 6 a AAT, AAR; b altitude, slope; c SMO; soil pH, SSC; d SOM, STC; e STN, STP of each sampling line

lake-terrestrial ecotone sampling line. The slopes of the six sampling lines were somewhat similar at $1-3 \%$. AAT, AAR, SMO, and soil nutrient content of BK1, YT1, and NT1 were significantly higher than those of NT1 and SC1-2. Moreover, soil pH and SSC of NT1 and SC1-2 were significantly higher than for other quadrats. The climatic and environmental factors (AAT and AAR), SMO, and soil nutrient conditions of the BK1 were the best among the six sampling lines, as they constitute the most favorable conditions for wetland herbs growth. Consequently, the coverage, species number, community diversity index, and community 
richness index of wetland herbs in the BK1 were the highest.

\section{Delimitation of lake-terrestrial ecotone wetland herbs}

The selection of a width for the MSWT window has an extremely important influence on the accuracy of the delimitation results. While selecting an extremely small window width leads to multi-peak interference [60], an extremely large window weakens the peaks [61]. Therefore, it is essential to determine the optimal window width of each sampling line for calculating the SED while using the MSWT to delimit the distribution width of wetland herbs. We used the BK1 sampling line as an example (Fig. 7), and considered 4, 6, 8, 10, and 12 sampling quadrats as the window width. At the window width of 10-12 sampling quadrats $(n=10,12)$, there was no peak, while at the window width of 4-8 $(n=4-8)$ sampling quadrats, a prominent peak emerged near quadrat 10 . The ecotone exhibited a greater species' diversity and enhanced community richness index as compared with the adjacent communities driven by the edge effect [62], Thus, the presence of the peak indicates that the plant community at this location had the greatest heterogeneity, and the ecological pattern of the plant community was changed at this location of the ecotone. Moreover, the presence of the prominent peak suggests that the area was the BK1 wetland herbs-mesophyte/xerophyte transition zone. This indicates that when the MSWT window width was 4-8 sampling quadrats $(n=4-8)$, it could better reflect the position of the plant transition zone. Moreover, compared to the window width of 6-8 sampling quadrats $(n=6-8)$, the peaks stemming from the window width of the four sampling quadrats $(n=4)$ were the most prominent, while the peak width was narrower. Notably, this was the optimal window width for BK1 (Fig. 7).

Similarly, the aforementioned method of selecting the most suitable window width was used to determine the optimal window width for YT1, NT1, NT2, SC1, and SC2. These corresponded to four sampling quadrats $(n=4)$ (Fig. 8a), four sampling quadrats $(n=4)$ (Fig. 8b), six sampling quadrats $(n=6)$ (Fig. $8 \mathrm{c})$, six sampling quadrats $(n=6)$ (Fig. 8d), and four sampling quadrats $(n=4)$ (Fig. 8f), respectively. Under the optimum window width of each sampling line, the wave peak was substantial, the peak value was higher, and the peak width was small, indicating that the MSWT was a suitable method for this study, and the wetland herbs of various sampling lines exhibited different distribution widths.

In combination with the field survey, the BK1 sampling line was considered as an example of Baksum Lake. This sampling line was set up with a sampling quadrat $(1 \mathrm{~m} \times 1 \mathrm{~m})$ for every $4 \mathrm{~m}$, with 17 sampling quadrats in total. The quadrats 1-11 were primarily included Commelina diffusa, Potentilla anserina, Plantago depressa, Ranunculus tanguticus, Selaginella nipponica, Duchesnea indica, Salvia przewalskii, and other wetland herbs. The quadrats $12-17$ primarily represented mesophytic and xerophytic plants such as Aristida triseta, Tripogon chinensis, Gueldenstaedtia verna, and Origanum vulgare L. The YT1 sampling line was considered as an example for Yamdroktso. The sampling line was set up with a sampling quadrat $(1 \times 1 \mathrm{~m})$ for every $4 \mathrm{~m}$, with a total of 16 sampling quadrats. The quadrats $1-12$ were mainly represented by Potentilla anserina, Ranunculus tanguticus, Plantago depressa, Aster tataricus, Polygonum sibiricum, and other wetland herbs. The quadrats 13-16 primarily included mesophytic and xerophytic
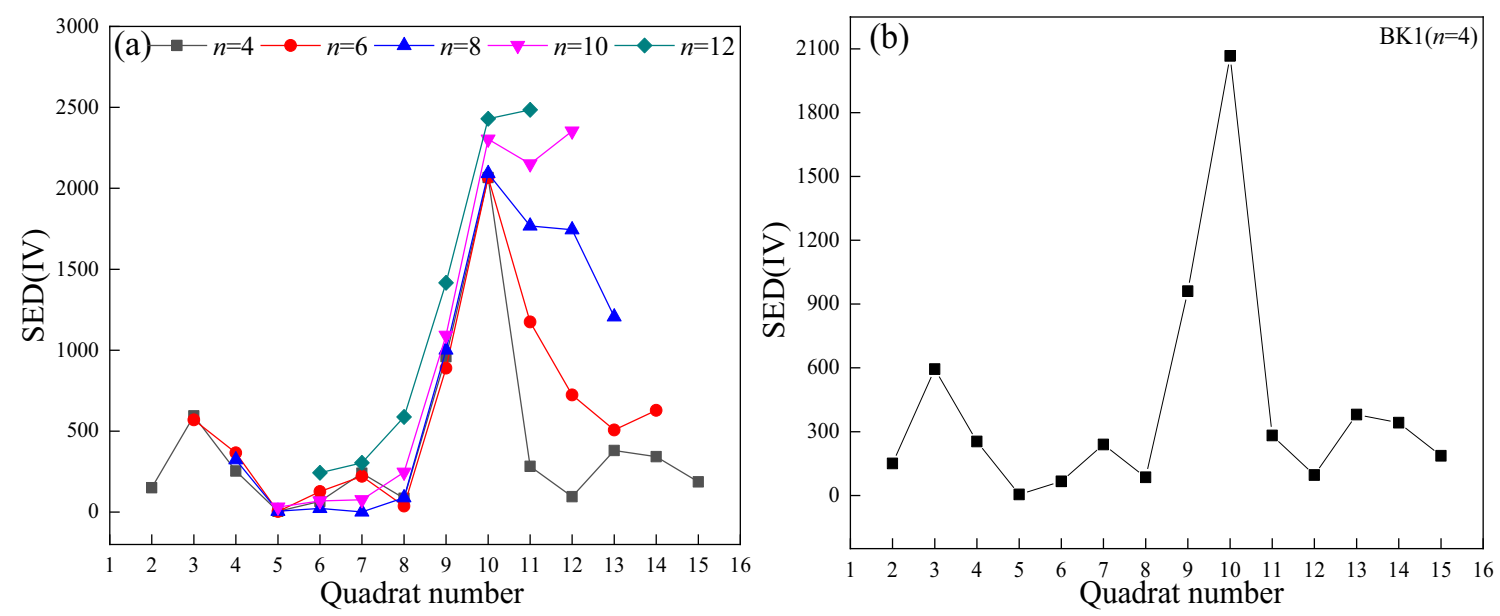

Fig. 7 a SED (IV) peak value under the different window width of (BK1), b optimal window width $(n=4)$ for BK1 

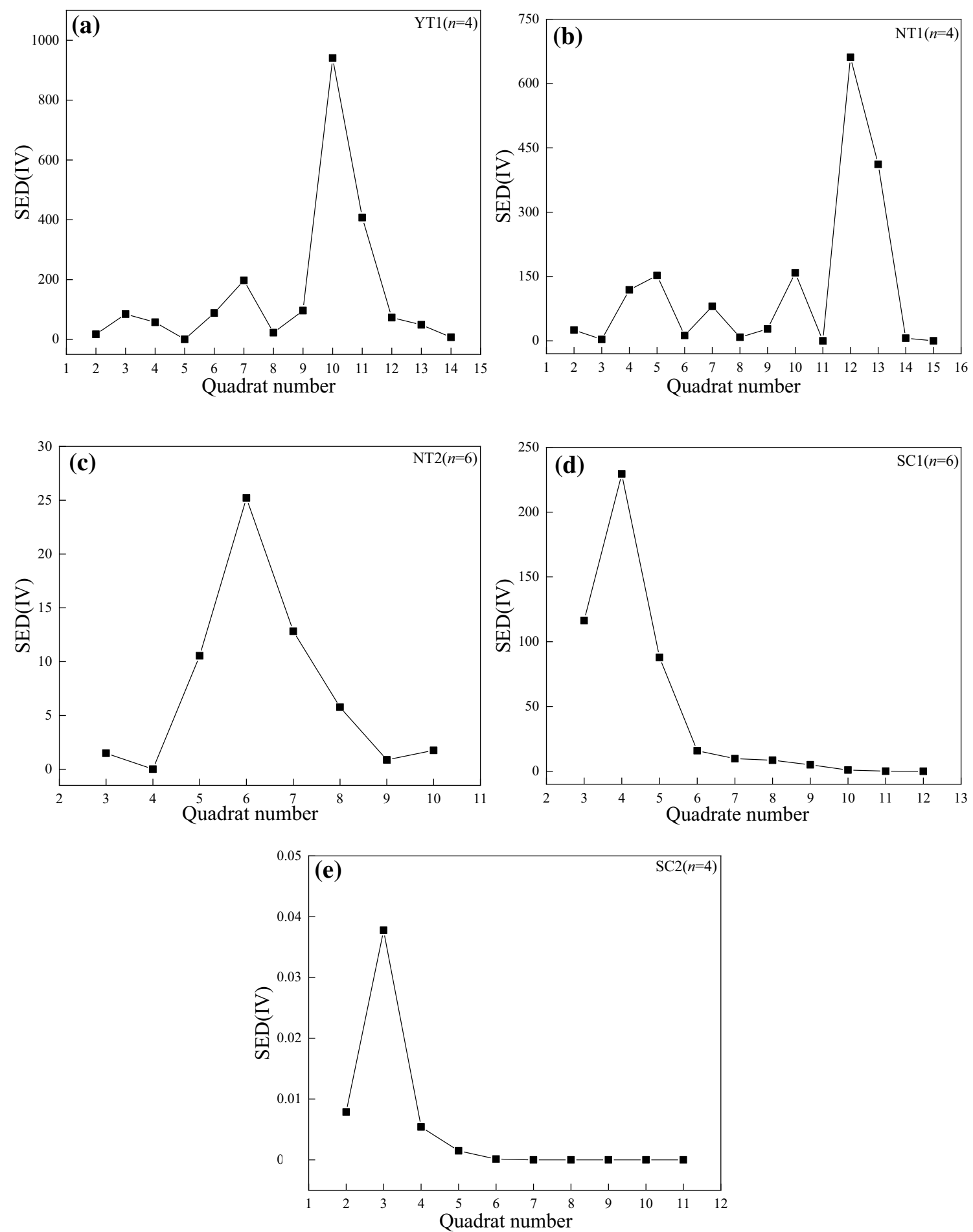

Fig. 8 a-e SED (IV) peak value under the suitable window of YT1, NT1, NT2, SC1, SC2

plants such as Oxytropis bicolor, Elymus dahuricus, and gray mesophytic and xerophytic plants such as Cyananthus incanus, Artemisia younghusbandii, and Tripogon chinensis. The NT1 sampling line was considered as an example for Namtso. The sampling line was set up with a $1 \times 1 \mathrm{~m}$ sampling quadrat for every $3 \mathrm{~m}$, with a total of 17 sampling quadrats. The quadrats $1-14$ were covered by Ranunculus tanguticus, Selaginella nipponica, Gentiana 
pseudoaquatica, Potentilla reptans, and other wetland herbs. There were also numerous drought-tolerant xerophytic herbs such as Potentilla bifurca L., Tibetia himalaica, Eriophorum comosum, and Dysphania aristata, in the quadrats 14-17. The SC1 sampling line was considered as an example for Siling Co. The sampling line was set up as a sampling quadrat $(1 \times 1 \mathrm{~m})$ for every $5 \mathrm{~m}$, with a total of 15 sampling quadrats. The quadrats 1-6 mainly included salt-tolerant wetland herbs Achnatherum splendens and Suaeda glauca, while the quadrats 7-15 were covered by xerophytes, Tripogon chinensis, and wet shrubs, Kalidium foliatum. This result confirms that the MSWT can be effectively used to delimit the distribution width of lake-terrestrial ecotone wetland herbs as the result was the same as the field survey wetland herbs community distribution boundary. Hence, the MSWT has promising prospects for the division of different community vegetation zones, directly proving that

Table 2 Width of wetland herbs distribution of lake-terrestrial ecotone on different lines

\begin{tabular}{lllll}
\hline Lake & $\begin{array}{l}\text { Sampling } \\
\text { line number }\end{array}$ & $\begin{array}{l}\text { Quadrat } \\
\text { spacing/m }\end{array}$ & $\begin{array}{l}\text { Peak width } \\
\text { end quadrat }\end{array}$ & Width/m \\
\hline Baksum Lake & BK1 & 4 & No.11 & 51 \\
Yamdroktso & YT1 & 4 & No.12 & 56 \\
Namtso & NT1 & 3 & No.14 & 53 \\
& NT2 & 3 & No.9 & 33 \\
Siling Co & SC1 & 5 & No.6 & 31 \\
& SC2 & 5 & No.4 & 19 \\
\hline
\end{tabular}

the MSWT can accurately delimit the growth boundary of wetland herbs [20], therefore, it is feasible to use the MSWT to delimit the upper boundary of lake-terrestrial ecotone. Thus, the wetland herbs distribution widths of the lake-terrestrial ecotone with the natural-wetland type of Baksum Lake, Yamdroktso, Namtso, and Siling Co are shown in Table 2, with values of $51,56,33-53 \mathrm{~m}$, and $19-31 \mathrm{~m}$, respectively.

\section{Factors affecting the distribution and diversity of wetland herbs}

PCA was used to identify the most important environmental factors affecting the distribution width of the wetland herbs. In particular, Fig. 9a shows that the Shannon-Wiener index (SW), Margalef index (M), SMO, soil $\mathrm{pH}$, and SSC were the most important factors affecting the distribution of wetland herbs. In fact, the ShannonWiener index and Margalef index were the principal factors affecting the distribution width as they were calculated based on the IV of wetland herbs in the laketerrestrial ecotone. We also explored the relationship between the plant diversity and the environmental factors to further determine the primary environmental factors affecting the distribution width of the wetland herbs.

Figure 9b shows the RDA among the Shannon-Wiener index $(\mathrm{SW})$, the Margalef index $(\mathrm{M})$, species richness (S), environmental factors, and the distribution width of wetland herbs. The Monte Carlo test shows that besides the influence of the distribution width of hygroscopic herbaceous plants, the Shannon-Wiener index and the
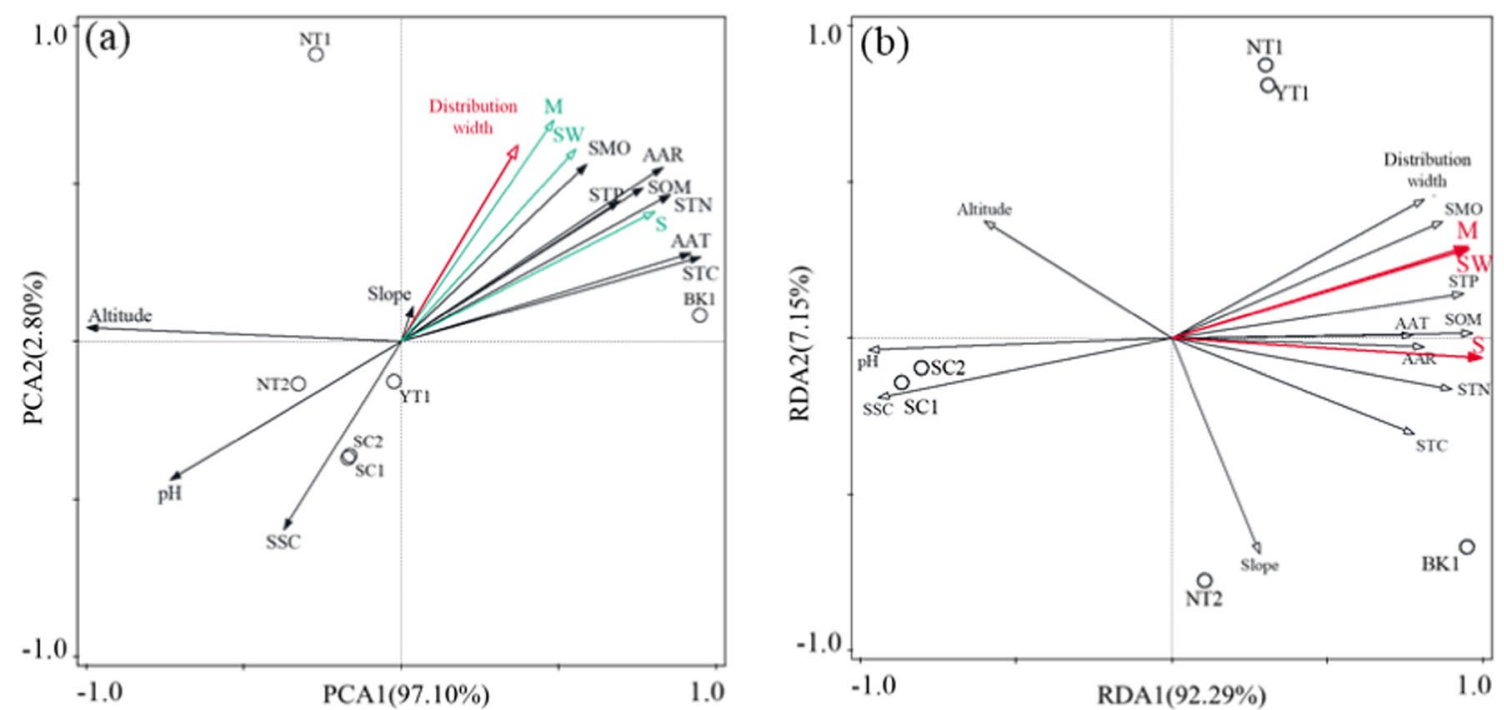

Fig. 9 a The principal component analysis (PCA) of the species richness (S), the Shannon-Wiener index (SW), the Margalef index (M) (green), environmental factors (black) and width of wetland herbs distribution (red); b The redundancy analysis (RDA) of the species richness (S), the Shannon-Wiener index (SW), the Margalef index (M) (red), environmental factors and width of wetland herbs distribution (black) 
Margalef index were primarily affected by SMO, STP, $\mathrm{SSC}$, and soil $\mathrm{pH}$, while the species richness was mostly affected by SOM, STN, SSC, soil pH, as well as AAT and AAR.

\section{Discussion}

Although the four analyzed lakes (Baksum Lake, Yamdroktso, Namtso, and Siling Co) are located at the Tibetan Plateau, there are obvious differences between them as seen from the natural environmental characteristics (Fig. 6), such as altitude, AAT, AAR, and soil nutrient content. In particular, AAT of the BK1 sampling line was $6.3{ }^{\circ} \mathrm{C}$ higher than that of SC2. The SMO, SOM, STC, STN, and STP contents of BK1 were 5.13, $4.11,6.80,41.88,3.81$ times those of $\mathrm{SC} 2$, respectively. However, the distribution width of the wetland herbs on BK1 disclosed the lowest altitude while the optimal climate conditions were not omnipresent in the area. However, through data investigation, it is not difficult to find that Baksum Lake has a lower altitude than Yamdroktso, Namtso, and the natural environment of Baksum Lake is more suitable for wetland herbs survival. However, through analysis and field survey, we found that the distribution of wetland herbs at the Baksum Lake sampling line (BK1) is not the widest (BK1: $51 \mathrm{~m}$; YT1: $56 \mathrm{~m}$; NT1: $53 \mathrm{~m}$ ), and the three sampling lines had the same wetland herbs. (Selaginella nipponica; Salvia przewalskii; Halerpestes sarmentosa; Suaeda glauca; Potentilla anserina L; Pedicularis longiflora). The previous study showed that with global warming and human activities increasing, high-altitude areas are the biodiversity hotspots, which provide numerous ecosystem services for the lowlands and become a sanctuary for plants at low altitudes [63]. In order to explain the reason and highlight the impact of human activities on the distribution of wetland herbs in the lake-terrestrial ecotone, we compared the lakes in the Middle-Lower Yangtze Plain that have better natural conditions and are seriously affected by human activities.

Table 3 Comparison of latitude and longitude, plant distribution width and characteristics of lakes in the Middle-Lower Yangtze Plain (Changtan Reservoir, Taihu Lake, Xiazhu Lake) and the Qinghai-Tibet Plateau lakes (Baksum Lake, Yamdroktso, Namtso, Siling Co)

\begin{tabular}{|c|c|c|c|c|c|c|c|c|}
\hline $\begin{array}{l}\text { Lake } \\
\text { district }\end{array}$ & Lake & Latitude & Longitude & Climate & $\begin{array}{l}\text { Wetland } \\
\text { herbs } \\
\text { distribution } \\
\text { width/(m) }\end{array}$ & $\begin{array}{l}\text { Margalef } \\
\text { index }\end{array}$ & $\begin{array}{l}\text { Shannon- } \\
\text { Wiener } \\
\text { index }\end{array}$ & $\begin{array}{l}\text { Species } \\
\text { richness }\end{array}$ \\
\hline \multirow{3}{*}{$\begin{array}{l}\text { The Mid- } \\
\text { dle-Lower } \\
\text { Yangtze } \\
\text { Plain, China }\end{array}$} & $\begin{array}{l}\text { Changtan } \\
\text { Reservoir }\end{array}$ & $28^{\circ} 03^{\prime} 00^{\prime \prime} \mathrm{N}-28^{\circ} 40^{\prime} 00^{\prime \prime} \mathrm{N}$ & $121^{\circ} 00^{\prime} 00^{\prime \prime E}-121^{\circ} 04^{\prime} 00^{\prime \prime E}$ & $\begin{array}{l}\text { Subtropical } \\
\text { monsoon } \\
\text { climate }\end{array}$ & $19-31$ & $1.50 \pm 0.24$ & $1.88 \pm 0.19$ & $16.33 \pm 3.23$ \\
\hline & Taihu Lake & $30^{\circ} 55^{\prime} 40^{\prime \prime} \mathrm{N}-31^{\circ} 32^{\prime} 58^{\prime \prime} \mathrm{N}$ & $119^{\circ} 52^{\prime} 32^{\prime \prime E}-120^{\circ} 36^{\prime} 10^{\prime \prime E}$ & $\begin{array}{l}\text { Subtropical } \\
\text { monsoon } \\
\text { climate }\end{array}$ & $11-19$ & $1.16 \pm 0.07$ & $1.52 \pm 0.14$ & $13.44 \pm 2.14$ \\
\hline & $\begin{array}{l}\text { Xiazhu } \\
\text { Lake }\end{array}$ & $30^{\circ} 31^{\prime} 28^{\prime \prime} \mathrm{N}-30^{\circ} 30^{\prime} 53^{\prime \prime} \mathrm{N}$ & $120^{\circ} 02^{\prime} 54^{\prime \prime} \mathrm{E}-120^{\circ} 01^{\prime} 52^{\prime \prime} \mathrm{E}$ & $\begin{array}{l}\text { Subtropical } \\
\text { monsoon } \\
\text { climate }\end{array}$ & $17-21$ & $1.22 \pm 0.09$ & $1.57 \pm 0.24$ & $12.55 \pm 3.10$ \\
\hline \multirow[t]{4}{*}{$\begin{array}{l}\text { The Qing- } \\
\text { hai-Tibet } \\
\text { Plateau, } \\
\text { China }\end{array}$} & $\begin{array}{l}\text { Baksum } \\
\text { Lake }\end{array}$ & $31^{\circ} 00^{\prime} 01^{\prime \prime} \mathrm{N}-31^{\circ} 22^{\prime} 53^{\prime \prime} \mathrm{N}$ & $93^{\circ} 53^{\prime} 37^{\prime \prime} \mathrm{E}-94^{\circ} 1^{\prime} 48^{\prime \prime} \mathrm{E}$ & $\begin{array}{l}\text { Plateau } \\
\text { temperate } \\
\text { monsoon } \\
\text { semi- } \\
\text { humid/ } \\
\text { semi-arid } \\
\text { climate }\end{array}$ & 51 & $1.02 \pm 0.11$ & $0.92 \pm 0.08$ & $12.60 \pm 2.27$ \\
\hline & $\begin{array}{l}\text { Yamdrok- } \\
\text { tso }\end{array}$ & $28^{\circ} 27^{\prime} 00^{\prime \prime} \mathrm{N}-29^{\circ} 12^{\prime} 00^{\prime \prime} \mathrm{N}$ & $90^{\circ} 08^{\prime} 00^{\prime \prime} \mathrm{E}-91^{\circ} 45^{\prime} 00^{\prime \prime} \mathrm{E}$ & $\begin{array}{l}\text { Plateau } \\
\text { sub-frigid } \\
\text { monsoon } \\
\text { semi-arid } \\
\text { climate }\end{array}$ & 56 & $0.94 \pm 0.28$ & $1.08 \pm 0.22$ & $6.67 \pm 2.38$ \\
\hline & Namtso & $30^{\circ} 30^{\prime} 00^{\prime \prime} \mathrm{N}-30^{\circ} 55^{\prime} 00^{\prime \prime} \mathrm{N}$ & $90^{\circ} 16^{\prime} 00^{\prime \prime} \mathrm{E}-91^{\circ} 03^{\prime} 00^{\prime \prime} \mathrm{E}$ & $\begin{array}{l}\text { Plateau } \\
\text { sub-frigid } \\
\text { monsoon } \\
\text { semi-arid } \\
\text { climate }\end{array}$ & $33-53$ & $0.74 \pm 0.23$ & $0.97 \pm 0.26$ & $6.34 \pm 1.80$ \\
\hline & Siling Co & $31^{\circ} 34^{\prime} 00^{\prime \prime} \mathrm{N}-31^{\circ} 51^{\prime} 00^{\prime \prime} \mathrm{N}$ & $88^{\circ} 33^{\prime} 00^{\prime \prime} \mathrm{E}-89^{\circ} 21^{\prime} 00^{\prime \prime} \mathrm{E}$ & $\begin{array}{l}\text { Plateau } \\
\text { sub-frigid } \\
\text { monsoon } \\
\text { semi-arid/ } \\
\text { plateau } \\
\text { cold arid } \\
\text { climate }\end{array}$ & $19-31$ & $0.33 \pm 0.04$ & $0.46 \pm 0.05$ & $2.28 \pm 1.05$ \\
\hline
\end{tabular}


In a previous study [54], we had investigated the distribution width of lake-terrestrial ecotone wetland herbs in the lakes of the Middle-Lower Yangtze Plain, which was basically in the same latitude range as for the four lakes analyzed in this study (Table 3 ). The species richness of the wetland herbs and the community diversity index of lake-terrestrial ecotones in the Middle-Lower Yangtze Plain were significantly higher than those four Tibetan lakes, whereas the presence of high-density population, agricultural planting, disturbance of the plants' growth area by road construction that yields, a smaller distribution width are all currently evidenced in Tibet [54]. As the altitude increases, the anthropogenic activities are generally weakened [64], thereby increasing the distribution width of wetland herbs. This pattern can also explain why the wetland herbs distribution width of the YT1 and NT1 was slightly wider than that of BK1. Moreover, our study showed that some wet plants, such as Potentilla anserina L., Duchesnea indica, and Plantago asiatica L., were present in the Middle-Lower Yangtze Plain and Baksum Lake, Namtso, and Yamdroktso at the same time. Had research suggested that high-altitude areas may become shelters for plants as the climate warms areas [65].

The four lakes on the Tibet Plateau are located far from each other; hence, the wet plants' quantity and species exhibited rather unique spatial distributions (Fig. 4). The NT2, SC1, and SC2 sampling lines were located in northern Tibet in the arid area of the desertification ecosystem. The area is arid and severely cold throughout the year, with extremely low soil nutrient content, low plant community species richness, and single community structure [66]. The PCA and the RDA analyses indicated that the water conditions, heat conditions, and soil nutrients were the main factors restraining the growth and distribution of plants in the dry and alpine regions [67-69]. Wang [70] reported that higher SMO and STN in alpine regions promoted an increase in plant biomass and richness, and vice versa. The PCA also proved that the Shannon-Wiener index and the Margalef index were the most important factors affecting the distribution width of the wetland herbs. Therefore, to determine the main influencing factors of the distribution width of lake-terrestrial ecotone wetland herbs, it is also necessary to explore the environmental factors affecting the Shannon-Wiener index, the Margalef index, and the species richness index.

The PCA also proved that the Shannon-Wiener index and the Margalef index were the most important factors affecting the distribution width of the wetland herbs. Therefore, to determine the main influencing factors of the distribution width of lake-terrestrial ecotone wetland herbs, it is also necessary to explore the environmental factors affecting the Shannon-Wiener index, the Margalef index, and the species richness index.
The distribution width of the wetland herbs, the Shannon-Wiener index, the Margalef index, and the species richness index exhibited significantly negative correlation with soil $\mathrm{pH}$ and salinity, indicating that the number of species and community richness in the sampling line had decreased with an increase in soil $\mathrm{pH}$ and salinity. It should be noted that soil salinity is stressful for the growth of wetland herbs [71], seemingly due to the decrease in the utilization of soil nutrients [72, 73]. The PCA also showed that soil $\mathrm{pH}$ and SSC exhibited significantly negative correlations with SOM, STC, STN, and STP contents, while SSC showed significantly negative correlations with SOM and STP. At the same time, high salinity and alkalinity restrained the growth of wetland herbs. Furthermore, wetland herbs present in SC1-2 were Suaeda glauca and Achnatherum splendens (Fig. 4), both species have high tolerance to salinity and alkalinity $[74,75]$. This also showed that different wet herbs species have different adaptabilities to soil pH and SSC [76]. Soil $\mathrm{pH}$ and SSC have substantially affected the distribution width of lake-terrestrial ecotone wetland herbs in the four lakes.

Yamdroktso, Namtso, and Siling Co are located in the relatively arid alpine areas. Therein, the composition, species richness, and diversity of plants in the ecosystem are primarily governed by soil moisture and salinity. The heterogeneity of soil moisture strongly affects the distribution of plants as well [77]. Vegetation distribution revealed that higher soil moisture was more conducive to the growth of wetland herbs, thus, resonating with the findings of Zhao and others [78]; they had found the prominent limiting factors for the growth of desert plants in arid areas. Therefore, soil water content was one of the principal factors affecting the distribution width of laketerrestrial ecotone wetland herbs in the four lakes.

The Pearson correlation analysis showed that the correlation coefficients among SMO, soil pH, SOM, STP, SSC content, and the distribution width of wetland herbs were 0.951 (at $\mathrm{p}<0.01$ significance), $-0.831,-0.902,0.821$, and 0.905 (at $\mathrm{p}<0.05$ significance). Moreover, the correlation between SMO, pH, SSC, SOM, and STP content was also significant. Fang [79] studied the lake wetland of Aibi Lake in an arid area and showed that the SMO of lakeside wetlands in alpine and arid areas was significantly affected by soil type, topography, climate, and structural factors as well. In addition, soil $\mathrm{pH}$ and soil nutrient content were significantly affected by soil moisture content.

A lake-terrestrial ecotone represents an important biological transition zone for the exchange of energy, material, and information between water and terrestrial ecosystems as a transition zone between lake water ecosystems and terrestrial ecosystems [80]. The distribution width of wetland herbs expresses the impact of lakes on 
the terrestrial environment. The distribution width of the lake-terrestrial ecotone vegetation community depends on the degree of tolerance of dominant species to major environmental stress factors [81], while water is a key factor affecting the ecological adaptation of lake-terrestrial ecotone plants and restraining the growth and distribution of plants [82]. Small differences in soil moisture content cause significant differences in the germination of wetland plant seeds, which subsequently affect the distribution of wetland plant communities [83]. There were significant climate differences among the analyzed lakes (Baksum Lake, Yamdroktso, Namtso, and Siling Co), leading to various magnitudes of soil $\mathrm{pH}, \mathrm{SMO}$, and soil nutrient content. These conditions caused the distribution of the lake-terrestrial ecotone wetland herbs in the Tibetan lake area to be influenced by multiple factors. From a macro-perspective, this was caused by the differences in climate conditions that determined the distribution width of the wetland herbs in Tibetan lakes. Plants have responded specifically to various temperatures and humidity caused by different micro-environment during the long-term evolution process in alpine and high-altitude regions and are able to effectively use solar energy for organic matter production under their respective temperature conditions [84]. Besides, biomass has a strong correlation with nutrient availability, microbial activity, and other biotic influences, which are more important drivers of biomass in alpine meadows [85]. It is well known that water is the key factor for plant biomass in alpine and high-altitude region. Previous studies have also found that the productivity of alpine grasslands is highly responsive to soil moisture content, indicating the importance of water conditions in constraining alpine vegetation production [86]. Further analysis also revealed that the species richness remained relatively low in low-moisture areas (NT2, SL1, SL2), regardless of soil temperature (Fig. 4). At the same time, the plant growth perspective emphasizes that the soil moisture content was the most important factor affecting the distribution width of wetland herbs.

\section{Conclusion}

The MSWT was successfully used to delimit the distribution width of lake-terrestrial ecotone wetland herbs in Tibet lakes. The delimitation results were consistent with the growth boundary of the wetland herbs in the field survey. $\mathrm{SMO}, \mathrm{pH}, \mathrm{SSC}$, and soil nutrient content were all important environmental factors affecting the distribution width of the lake-terrestrial ecotone wetland herbs in Tiben lakes, and SMO was found the most important one. In the similar climate condition, the stronger the human interference, the shorter the distribution width of lake-terrestrial ecotone wetland herbs. Since the distribution width of wetland herbs reflected the upper boundary of the lake-terrestrial ecotone, the present study provides a theoretical basis for the lake management and ecological restoration.

\section{Abbreviations}

MSWT: Moving split-window technology; SED: Squared euclidean distance; IV: Important value; DCA: Detrended correspond analysis; PCA: Principal component analysis; RDA: Redundancy analysis; BK: Baksum lake; NT: Namtso; YT: Yamdroktso; SC: Siling Co; AAR: Annual average rainfall; AAT: Annual average temperature; SCC: Soil salt content; SMO: Soil moisture; SOM: Soil organic matter; STC: Soil total carbon; STN: Soil total nitrogen; STP: Soil total phosphorus; SMT:The Standards, Measurements and Testing Programme Method; SW: The Shannon-Wiener index; M: The Margalef index; S: Species richness.

\section{Acknowledgements}

Thanks to Fu-xing Liu and Jun-li Wang of Shanghai Academy of Agricultural Sciences for overcoming physical discomfort caused by high-altitude hypoxia, giving help on the field investigation. We further thank assistance provided by Ecology and Environment Bureau of Tibet Autonomous Region in this study.

\section{Authors' contributions}

PRZ: field survey, sampling design, data analysis, manuscript draft writing; $\mathrm{CHL}$ : field survey, validation, resources, writing - review and editing, supervision; CY: validation, resources, writing — review and editing, supervision; PRZ, $H W$, WWW, and $Y Z$ : field survey, sampling; $X Y Z$ : sampling design, review. All authors read and approved the final manuscript.

\section{Funding}

National Major Science and Technology Program for Water Pollution Control and Treatment, China (No.2012ZX07101-009); Transformation and Promotion of Ecological Space Management and Control Technology, China (No.2020-JY-018).

\section{Availability of data and materials}

Not applicable.

\section{Declarations}

Ethics approval and consent to participate

Not applicable.

Consent for publication

Not applicable.

\section{Competing interests}

The authors declare that they have no competing interest.

\section{Author details}

${ }^{1}$ National Engineering Laboratory for Lake Pollution Control and Ecological Restoration, State Environmental Protection Key Laboratory for Lake Pollution Control, Chinese Research Academy of Environmental Sciences, Beijing 100012, China. ${ }^{2}$ Chunliang Oil Production Plant, Shengli Oilfield Company, Dongying 257000 , China. ${ }^{3}$ College of Life and Environmental Science, Wenzhou University, Wenzhou 325035, China.

Received: 14 November 2021 Accepted: 21 January 2022

Published online: 14 February 2022

\section{References}

1. Ye C, Li C, Deng T (2015) Structures and ecological functions of lake littoral zones. Res Environ Sci 28:171-181. https://doi.org/10.13198/j.issn. 1001-6929.2015.02.02 
2. Simmons B, Woog R, Dimitrov V (2007) Living on the edge: A ComplexityInformed exploration of the human-water relationship. World Futures 63(3-4):275-285. https://doi.org/10.1080/02604020601174927

3. Ye C, Li C, Chen X, Jiao X, Lu S (2012) Classification and ecological restoration modes for the littoral zone of Lake Taihu. Journal of Lake Sciences 24:822-828. https://doi.org/10.18307/2012.0603

4. Makarewicz JC, Lewis TW, Pennuto CM, Atkinson JF, Edwards WJ, Boyer GL, Howell ET, Thomas G (2012) Physical and chemical characteristics of the nearshore zone of Lake Ontario. J Great Lakes Res 38:21-31. https:// doi.org/10.1016/j.jg|r.2011.11.013

5. Bettez ND, Groffman PM (2012) Denitrification potential in stormwater control structures and natural riparian zones in an urban landscape. Environ Sci Technol 46:10909-10917

6. Nishihiro J, Washitani I (2007) Restoration of lakeshore vegetation using sediment seed banks; studies and practices in Lake Kasumigaura, Japan. Glob Environ Res 11:171-177

7. Chen J, Kong D, Fan Y, Zhao L, Li J, Yang F (2012) Restoration project of embankment and substrata in Dianchi's lakeshore. Environ Sci Technol (China) 35:157-179. https://doi.org/10.3969/j.issn.1003-6504.2012.06.034

8. Wang H, Song C, Liu X, Li K (2012) Lakeshore overview of lake chaohu and ecological rehabilitation schemes for shoreline and littoral zones. Resour Environ Yangtze Basin 21:63-64

9. Chen F, Lu S, Hu X, He Q, Feng C, Xu Q, Chen N, Ngo H, Guo H (2019) Multi-dimensional habitat vegetation restoration mode for lake riparian zone, Taihu, China. Ecol Eng 134:56-64. https://doi.org/10.1016/j.ecoleng. 2019.05.002

10. Yuan X, Zhang Y, Liu H, Xiong S, Li B, Deng W (2013) The littoral zone in the Three Gorges Reservoir, China: challenges and opportunities. Environ Sci Pollut Res 20:7092-7102. https://doi.org/10.1007/s11356-012-1404-0

11. Tao Y, Wu G, Zhang Y (2017) Dune-scale distribution pattern of herbaceous plants and their relationship with environmental factors in a saline-alkali desert in Central Asia. Sci Total Environ 576:473-480. https:// doi.org/10.1016/j.scitotenv.2016.10.102

12. Liu Y, Ren W, Shu T, Xie C, Jiang J, Yang S (2015) Current status and the long-term change of riparian vegetation in last fifty years of Lake Honghu. Resour Environ Yangtze Basin 24:38-45

13. Tölgyesi C, Körmöczi L (2012) Structural changes of a Pannonian grassland plant community in relation to the decrease of water availability. Acta Bot Hungar 54:413-431. https://doi.org/10.1556/ABot.54.2012.3-4.17

14. Sun R, Chen W, Song X, Luo Y, Liu L (2019) Distribution characteristics and edge effect of soil water and salt in silvopastoral system of the Yellow River Delta, China. Chin J Appl Ecol 30:2549-2557. https://doi.org/10. 13287/j.1001-9332.201908.003

15. Hufkens K, Scheunders P, Ceulemans R (2009) Ecotones in vegetation ecology: methodologies and definitions revisited. Ecol Res 24:977-986. https://doi.org/10.1007/s11284-009-0584-7

16. Körmöczi L, Bátori Z, Erdős L, Tölgyesi C, Zalatnai M, Varró C (2016) The role of randomization tests in vegetation boundary detection with moving split-window analysis. J Veg Sci 27:1288-1296. https://doi.org/10. $1111 /$ jvs. 12439

17. Ou X, Liu X, Zhang Z, Wang W, Shi W, Fang X (2011) Advances in ecotone width determination and its impact factors. Ecol Sci 30:88-96. https://doi. org/10.3969/j.issn.1008-8873.2011.01.016

18. Wang T, Ou X, Zhang Z, Liu X, Wang L, Sun Z, He B, Li F (2012) Measurement of ecotone width between agro-ecosystem and forest ecosystems after grain for green program. J Yunnan Univ Nat Sci Edn 34:604-612

19. Xiong D, Ou X, Huang W, Yang J, Wang T, Guo J, Zhang Z (2014) Measurement of eco-tone width between agro-forest ecosystems based on soil nutrients. Ecol Sci 33:594-602. https://doi.org/10.3969/j.issn.1008$8873,2014.03 .030$

20. Su X, Wang Z (2017) Research on boundary definition and plant community diversity of wetland-grassland ecotone: a case ecotone: a Wetland in Ningxia. For Res Manage 1:63-69. https://doi.org/10.13466/j.cnki.lyzygl. 2017.01.012

21. Li H, Liu X, Zhang K, Miao J, Siraj M (2016) Definition of wetland-dry grassland ecotone and vegetation stability in the Nanhaizi wetland in Yanchi, Ningxia. Pratacult Sci 33:170-176. https://doi.org/10.11829/j.issn. 1001-0629.2016.0462

22. Li W, Xu Q, Li J, Li SL, Yu Q, Zhang Z (2017) Quantification of ecotone width of returned forest land from farmland based on specific leaf area.
J West China For Sci 46:117-121. https://doi.org/10.16473/j.cnki.xblyk X1972.2017.01.022

23. Humphries NE, Queiroz N, Dyer JR, Pade NG, Musyl MK, Schaefer KM, Fuller DW, Brunnschweiler JM, Doyle TK, Houghton JD, Hays GC (2010) Environmental context explains Lévy and Brownian movement patterns of marine predators. Nature 465:1066-1069. https://doi.org/10.1038/ nature09116

24. Pärn J, Remm K, Mander Ü (2010) Correspondence of vegetation boundaries to redox barriers in a Northern European moraine plain. Basic Appl Ecol 11:54-64. https://doi.org/10.1016/j.baae.2009.08.001

25. Pandita S, Dutt HC (2020) Land use induced blurring of forest-grassland transition in north-west Himalaya - A case study using Moving Split Window boundary detection technique. J Mt Sci 17:3085-3096

26. Xie Y, Qiu K, Xu D, Shi X, Qi T, Pott R (2015) Spatial heterogeneity of soil and vegetation characteristics and soil-vegetation relationships along an ecotone in Southern Mu Us Sandy Land, China. J Soils Sediments 15:1584-1601. https://doi.org/10.1007/s11368-015-1114-6

27. Fiqueiredo FO, Zuquim G, Tuomisto H, Moulatlet GM, Balslev H, Costa FR (2018) Beyond climate control on species range: the importance of soil data to predict distribution of Amazonian plant species. J Biogeogr 45:190-200. https://doi.org/10.1111/jbi.13104

28. Gong X, Brueck H, Giese KM, Zhang L, Sattelmacher B, Lin S (2008) Slope aspect has effects on productivity and species composition of hilly grassland in the Xilin River Basin, Inner Mongolia, China. J Arid Environ 72:483-493. https://doi.org/10.1016/j.jaridenv.2007.07.001

29. Torma A, Császár P (2013) Species richness and composition patterns across trophic levels of true bugs (Heteroptera) in the agricultural landscape of the lower reach of the Tisza River Basin. J Insect Conserv 17:35-51. https://doi.org/10.1007/s10841-012-9484-1

30. Calhoun AJ, Mushet DM, Bell KP, Boix D, Fitzsimons JA, Isselin-Nondedeu F (2017) Temporary wetlands: challenges and solutions to conserving a 'disappearing' ecosystem. Biol Cons 211:3-11. https://doi.org/10.1016/j. biocon.2016.11.024

31. Petersen JE, Brandt EC, Grossman JJ, Allen GA, Benzing DH (2015) A controlled experiment to assess relationships between plant diversity, ecosystem function and planting treatment over a nine year period in constructed freshwater wetlands. Ecol Eng 82:531-541. https://doi.org/ 10.1016/j.ecoleng.2015.05.002

32. Wang S, Dou H (eds) (1998) Records of China Lake. Science Press Beijing, Beijing

33. Lin Q, Xu L, Hou J, Liu Z, Jeppesen E, Han B (2017) Responses of trophic structure and zooplankton community to salinity and temperature in Tibetan lakes: Implication for the effect of climate warming. Water Res 124:618-629. https://doi.org/10.1016/j.watres.2017.07.078

34. Zhao W, Xiong D, Wen F, Wang X (2020) Lake area monitoring based on land surface temperature in the Tibetan Plateau from 2000 to 2018. Environ Res Lett 15:084033. https://doi.org/10.1088/1748-9326/ab9b41

35. Huang X, Sillanpää M, Gjessing ET, Peräniemi S, Vogt RD (2010) Environmental impact of mining activities on the surface water quality in Tibet: Gyama valley. Sci Total Environ 408:4177-4184

36. Wang $X$ (2014) Sustainable development in Tibet requires control of agricultural nonpoint pollution. Environ Sci Technol 48:8944-8945. https:// doi.org/10.1016/j.scitotenv.2010.05.015

37. Zhang H, Wang Z, Zhang Y, Hu Z (2012) The effects of the Qinghai-Tibet railway on heavy metals enrichment in soils. Sci Total Environ 439:240248. https://doi.org/10.1016/j.scitotenv.2012.09.027

38. Tong K, Su F, Li C (2020) Modeling of Water Fluxes and Budget in Nam Co Basin during 1979-2013. J Hydrometeorol 21:829-844. https://doi.org/10. 1175/JHM-D-19-0135.1

39. Li D, Li Y, Ma B, Dong G, Wang L, Zhao J (2009) Lake-level fluctuations since the Last Glaciation in Selin Co (lake), Central Tibet, investigated using optically stimulated luminescence dating of beach ridges. Environ Res Lett 4:045204. https://doi.org/10.1088/1748-9326/4/4/045204

40. Jia X, Wang D, Liu F, Dai Q (2020) Evaluation of highway construction impact on ecological environment of Qinghai-Tibet Plateau. EEMJ 19:1157-1166

41. Wu Y, Wang S, Ni Z, Li H, May L, Pu J (2021) Emerging water pollution in the world's least disturbed lakes on Qinghai-Tibetan Plateau. Environ Pollut 272:116032. https://doi.org/10.1016/j.envpol.2020.116032

42. Li K, Liu X, Herzschuh U, Wang Y (2016) Rapid climate fluctuations over the past millennium: evidence from a lacustrine record of Basomtso Lake, 
southeastern Tibetan Plateau. Sci Rep 6:1-9. https://doi.org/10.1038/ srep24806

43. Zhang X, Sun R, Zhu L (2012) Lake water in the Yamzhog Yumco Basin in South Tibetan region: quality and evaluation. J Glaciol Geocryol 34:950-958. https://doi.org/10.1007/s11783-011-0280-z

44. Feng J, Chen F, Hu H (2017) Isotopic study of the source and cycle of sulfur in the Yamdrok Tso basin, Southern Tibet, China. Appl Geochem 85:61-72. https://doi.org/10.1016/j.apgeochem.2017.09.005

45. Yang K, Wang J, Lei Y, Chen Y, Zhu L, Ding B, Qin J (2016) Quantifying evaporation and its decadal change for Lake Nam Co, central Tibetan Plateau. J Geophys Res 121:7578-7591. https://doi.org/10.1002/2015J D024523

46. Wang J, Zhu L, Daut G, Ju J, Lin X, Wang Y, Zhen X (2009) Investigation of bathymetry and water quality of Lake Nam Co, the largest lake on the central Tibetan Plateau, China. Limnology 10:149-158. https://doi.org/10. 1007/s10201-009-0266-8

47. Deng Y, Liu P, Conrad R (2019) Effect of temperature on the microbial community responsible for methane production in alkaline NamCo wetland soil. Soil Biol Biochem 132:69-79. https://doi.org/10.1016/j.soilb io.2019.01.024

48. Kou Q, Lin X, Wang J, Yu S, Kai J, Laug A, Zhu L (2021) Spatial distribution of $\mathrm{n}$-alkanes in surface sediments of Selin Co Lake, central Tibetan Plateau, China. J Paleolimnol 65:53-67. https://doi.org/10.1007/ s10933-020-00148-8

49. Guo Y, Zhang Y, Ma N, Xu J, Zhang T (2019) Long-term changes in evaporation over Siling Co Lake on the Tibetan Plateau and its impact on recent rapid lake expansion. Atmos Res 216:141-150. https://doi.org/10.1016/j. atmosres.2018.10.006

50. Chen Y (2001) Hydrographic features of Serling Co, North Tibetan Plateau. J Lake Sci 13:21-28. https://doi.org/10.18307/20010104

51. Erdős L, Zalatnai M, Bátori Z, Körmöczi L (2014) Transitions between community complexes: a case study analysing gradients through mountain ridges in South Hungary. Acta Bot Croat 73:63-77. https://doi.org/10. 2478/botcro-2013-0009

52. Dale MR, Fortin MJ (2014) Spatial analysis: a guide for ecologists. Cambridge University Press, Cambridge, p 425p

53. Erdős L, Bátori Z, Tölgyesi C, Körmöczi L (2014) The moving split-window (MSW) analysis in vegetation science-an overview. Appl Ecol Environ Res 12(3):787-805. https://doi.org/10.15666/aeer/1203_787805

54. Zheng P, Shang X, Ye C, Li C, Zheng X, Dai W, Wei W (2021) Delimiting the radiant belt toward land of lake-terrestrial ecotone with natural-wetland type. Res Environ Sci 34:953-963. https://doi.org/10.13198/j.issn.10016929.2020.12.29

55. Schmugge TJ, Jackson TJ, McKim HL (1980) Survey of methods for soil moisture determination. Water Resour Res 16:961-979. https://doi.org/10. 1029/WR016i006p00961

56. Wang QM, Huo ZL, Zhang LD, Wang JH, Zhao Y (2016) Impact of saline water irrigation on water use efficiency and soil salt accumulation for spring maize in arid region of China. Agric Water Manag 163:125-138. https://doi.org/10.1016/j.agwat.2015.09.012

57. Schofield RK, Taylor AW (1955) The measurement of soil pH. Soil Sci Soc Am J 19(2):164-167. https://doi.org/10.2136/sssaj1955.036159950019000 20013x

58. Zhang B (2013) Study on Distribution characteristics and flux of organic matter, nitrogen and phosphorus in the soil of WLFZ of Three Gorges Reservoir. Chongqing University, Chongqing, p 124p

59. Ruban V, López-Sánchez JF, Pardo P, Rauret G, Muntau H, Quevauviller P (1999) Selection and evaluation of sequential extraction procedures for the determination of phosphorus forms in lake sediment. J Environ Monit 1:51-56. https://doi.org/10.1039/A8077781

60. Choesin D, Boerner REJ (2002) Vegetation boundary detection: a comparison of two approaches applied to field data. Plant Ecol 158:85-96. https://doi.org/10.1023/A:1014720508155

61. Kröger R, Khomo LM, Levick S, Rogers KH (2009) Moving window analysis and riparian boundary delineation on the Northern Plains of Kruger National Park, South Africa. Acta Oecologica 35:573-580. https://doi.org/ 10.1016/j.actao.2009.05.007

62. Lantman IMVS, Hertzog LR, Vandegehuchte ML, Martel A, Verheyen K, Lens L, Bonte D (2020) Forest edges, tree diversity and tree identity change leaf miner diversity in a temperate forest. Insect Conserv Diver 13:10-22. https://doi.org/10.1111/icad.12358
63. Rixen C, Wipf S (2017) Non-equilibrium in alpine plant assemblages: shifts in Europe's summit floras. High Mountain Conserv Changing World 62:285-303. https://doi.org/10.1007/978-3-319-55982-7

64. Nogués-Bravo D, Araújo MB, Romdal T, Rahbek C (2008) Scale effects and human impact on the elevational species richness gradients. Nature 453:216-219. https://doi.org/10.1038/nature06812

65. Shimono A, Zhou H, Shen H, Hirota M, Ohtsuka T, Tang Y (2010) Patterns of plant diversity at high altitudes on the Qinghai-Tibetan Plateau. Journal of Plant Ecology 3:1-7. https://doi.org/10.1093/jpe/rtg002

66. Huo J, Liu W, Liu J, Li H, Xu Y, Maria.N. (2017) Driving forces of desert plant characteristics in a desert oasis transitional zone in Driving forces of desert plant characteristics in a desert oasis transitional zone in FuKang, Xinjiang, China. Acta Ecol Sin 37:1-10. https://doi.org/10.5846/stxb2 01610282199

67. Long T, Wang J, Li J, Feng Y, Wu B, Lu Q (2017) Plant diversity and its environmental explanation in Gobi district of northern Qinghai-Tibet Plateau, northwestern China. J Beijing For Univ 39:17-24. https://doi.org/ 10.13332/j.1000-1522.20170395

68. Liu L (2016) The relationship between plant diversity and climate factors in different grassland types of Xinjiang. Xinjiang Agricultural University, Urumqi, p 68p

69. Fayech D, Tarhouni I (2020) Climate variability and its effect on normalized difference vegetation index (NDVI) using remote sensing in semi-arid area. Model Earth Syst Environ. https://doi.org/10.1007/ S40808-020-00896-6

70. Wang Z, Yang G, Yi S, Chen S, Wu Z, Guan J, Zhao C, Zhao Q, Ye B (2012) Effects of environmental factors on the distribution of plant communities in a semi-arid region of the Qinghai-Tibet Plateau. Ecol Res 27:667-675. https://doi.org/10.1007/s11284-012-0951-7

71. Qiao B, Huang W, He T, Su Z, Feng Y (2018) Analysis on the diversity of halophyte plant community and soil salinity in beach-wetland of ZhenLake of Ningxia. Acta Botan Boreali-Occiden Sin 38:324-331

72. Tian L, Zhao L, Wu X, Fang H, Zhao Y, Yue G, Liu G, Chen H (2017) Vertical patterns and controls of soil nutrients in alpine grassland: Implications for nutrient uptake. Sci Total Environ 607:855-864. https://doi.org/10.1016/j. scitotenv.2017.07.080

73. Iqbal T (2018) Rice straw amendment ameliorates harmful effect of salinity and increases nitrogen availability in a saline paddy soil. J Saudi Soc Agric Sci 17:445-453. https://doi.org/10.1016/j.jssas.2016.11.002

74. Kou X, Li J, Liu H, Li B, Yu X, Cao X, Liu D, Wen L, Zhuo Y, Wang L (2020) Characteristics of bacterial biodiversity and community structure in non-rhizosphere soils along zonal distribution of plants within littoral wetlands in inner Mongolia, China. Glob Ecol Conserv. https://doi.org/10. 1016/j.gecco.2020.e01310

75. Li J, Hussain T, Feng X, Guo K, Chen H, Yang C, Liu X (2019) Comparative study on the resistance of Suaeda glauca and Suaeda salsa to drought, salt, and alkali stresses. Ecol Eng 140:105593. https://doi.org/10.1016/j. ecoleng.2019.105593

76. Zhao M, Zhao R, Zhang L, Zhao H, Zhou Y (2019) Plant diversity and its relationship with soil factors in the middle reaches of the Heihe River based on the soil salinity gradient. Acta Ecol Sin 39:4116-4126. https:// doi.org/10.5846/stxb201806231386

77. Närhi P, Middleton M, Hyvönen E, Piekkari M, Sutinen R (2010) Central boreal mire plant communities along soil nutrient potential and water content gradients. Plant Soil 331:257-264. https://doi.org/10.1007/ s11104-009-0250-4

78. Zhao X, He X, Yang X, Zhang X, Lv G (2017) Effects of soil moisture and salt on desert plant biodiversity in Ebinur Lake Basin of Xinjiang, China. J Arid Land Res Environ 31:76-82. https://doi.org/10.13448/j.cnki.jalre.2017. 182

79. Fang L, Li Y, Li F, Zhu HQ (2019) Analysis of spatial variation of soil moisture-salinity-nutrient in Ebinur Lake wetlands, China. J Agro Environ Sci 38:157-167. https://doi.org/10.11654/jaes.2018-0632

80. Osborne LL, Kovacic DA (1993) Riparian vegetated buffer strips in waterquality restoration and stream management. Freshw Biol 29:243-258. https://doi.org/10.1111/j.1365-2427.1993.tb00761.x

81. Casanova MT, Brock MA (2000) How do depth, duration and frequency of flooding influence the establishment of wetland plant communities? Plant Ecol 147:237-250. https://doi.org/10.1023/A:1009875226637

82. Fu B, Wang Y, Xu P, Wang D (2009) Changes in overland flow and sediment during simulated rainfall events on cropland in hilly areas of the 
Sichuan Basin, China. Prog Nat Sci 19:1613-1618. https://doi.org/10 1016/j.pnsc.2009.07.001

83. Shen H, Tang Y, Washitani I (2009) Ecological responses of Primula nutans to centimeter-scale topographic and environmental variability in an alpine wetland. Ecol Res 24:75-81. https://doi.org/10.1007/ s11284-008-0483-3

84. Niu Y, Yang S, Zhou J, Chu B, Ma S, Zhu H, Hua L (2019) Vegetation distribution along mountain environmental gradient predicts shifts in plant community response to climate change in alpine meadow on the Tibetan Plateau. Sci Total Environ. https://doi.org/10.1016/j.scitotenv. 2018.08.390

85. Little CJ, Wheeler JA, Sedlacek J, Cortés AJ, Rixen C (2016) Small-scale drivers: the importance of nutrient availability and snowmelt timing on performance of the alpine shrub Salix herbacea. Oecologia 180:0151024. https://doi.org/10.1007/s00442-015-3394-3

86. Liu H, Mi Z, Lin L, Wang Y, Zhang Z, Zhang F, Wang H, Liu L, Zhu B, Cao G, Zhao X (2018) Shifting plant species composition in response to climate change stabilizes grassland primary production. Proc Natl Acad Sci 115:4051-4056. https://doi.org/10.1073/pnas.1700299114

\section{Publisher's Note}

Springer Nature remains neutral with regard to jurisdictional claims in published maps and institutional affiliations.

\section{Submit your manuscript to a SpringerOpen ${ }^{\circ}$ journal and benefit from:}

- Convenient online submission

- Rigorous peer review

- Open access: articles freely available online

- High visibility within the field

- Retaining the copyright to your article

Submit your next manuscript at $\boldsymbol{\nabla}$ springeropen.com 